\title{
DIETARY MISTAKES OF POLISH ATHLETES IN RELATION TO THE FREQUENCY OF CONSUMING FOODS RECOMMENDED IN THE SWISS FOOD PYRAMID FOR ACTIVE PEOPLE
}

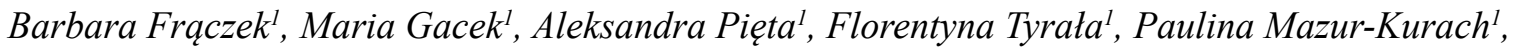 \\ Ewa Karpecka ${ }^{I}$
}

${ }^{1}$ Faculty of Sports Medicine and Human Nutrition, University School of Physical Education in Kraków, Poland

\begin{abstract}
Background: Mistakes in dietary choices and an unbalanced diet reduce the exercise capacity of athletes. Nutritional behaviours are conditioned by environmental and individual factors.

Objective: The aim of the study was to assess the scale of improper eating behaviours among high-performance Polish athletes depending on gender, sports level and type of discipline.

Material and methods: The study was conducted among 610 athletes ( 391 men and 219 women). The group consisted of 289 athletes of individual disciplines and 321 team sports athletes representing the championship sports class (282 individuals) as well as the first and second classes ( 328 subjects). The authors' validated nutritional behaviour questionnaire was used, referring to the recommendation of the Swiss nutrition pyramid for athletes. In statistical analysis, the $\mathrm{Chi}^{2}$ test was applied $(\alpha=0.05)$.

Results: Athletes most often demonstrated improper behaviours regarding: insufficient frequency of consuming vegetable fats $(61.78 \%)$, fruits $(59.89 \%)$, wholegrain products $(59.90 \%)$, vegetables $(53.62 \%)$ and dairy products $(52.09 \%)$, and not limiting the intake of energy drinks (59.89\%). Compared to women, men, to a larger extent, did not include the following in their daily diet: raw vegetables $(p<0.001)$, wholegrain products $(p<0.05)$ and vegetable fats $(p<0.01)$. Significantly more often, they also did not limit the consumption of: animal fats $(p<0.001)$, sweetened carbonated beverages $(p<0.001)$, energy drinks $(p<0.05)$ or fast food products $(p<0.001)$. Women consumed meals less regularly $(p<0.01)$, rarely ate fish $(p<0.01)$, and were more likely to be inadequately hydrated $(p<0.05)$. Athletes training individual sports disciplines compared to those training team sports consumed hydrating beverages $(p<0.001)$ less often, but included fruit in their daily diet more frequently $(p<0.05)$. Athletes from the master class consumed meals irregularly $(p<0.01)$ in a smaller percentage than athletes with a lower sports class, not limiting animal fats $(p<0.05)$ and implementing inadequate hydration $(p<0.05)$.

Conclusions: The scale of incorrect nutrition choices among athletes indicated variations depending on gender, sports level and type of sport practiced, with incorrect behaviours more often presented by men than women and competitors with a lower sports level (non-master class). The nature of the performed discipline was a factor less differentiating the nutritional choices of athletes.
\end{abstract}

Key words: athletes, nutritional behaviours, dietary conditions, gender, sport level, nature of sport

\section{STRESZCZENIE}

Wprowadzenie: Wadliwe wybory żywieniowe i niezbilansowana dieta wpływają na obniżenie zdolności wysiłkowych sportowców. Zachowania żywieniowe są warunkowane czynnikami środowiskowymi i osobniczymi.

Cel: Celem badań była ocena skali nieprawidłowych zachowań żywieniowych polskich sportowców wyczynowych w zależności od płci, poziomu sportowego i rodzaju uprawianej dyscypliny.

Material i metody: Badania przeprowadzono wśród 610 sportowców (391 mężczyzn i 219 kobiet). Grupę stanowiło 289 zawodników dyscyplin indywidualnych i 321 zawodników dyscyplin zespołowych, reprezentujących klasę sportowa mistrzowską (282 osób) oraz pierwszą i drugą (328 osób). Zastosowano autorski walidowany kwestionariusz zachowań żywieniowych, nawiązujący do rekomendacji szwajcarskiej piramidy żywienia dla sportowców. W analizie statystycznej zastosowano test $C h i^{2}(\alpha=0,05)$.

Wyniki: Sportowcy najczęściej wykazywali nieprawidłowości dotyczące: niewystarczającej częstości spożywania thuszczów roślinnych $(61,78 \%)$, owoców $(59,89 \%)$, pełnoziarnistych produktów zbożowych $(59,90 \%)$, warzyw $(53,62 \%)$

Corresponding author: Barbara Frączek, Institute of Biomedical Sciences, University School of Physical Education, Al. Jana Pawła II 78, 31-571 Kraków, Phone: 00481268310 02, Fax: 004812683 12 23, e-mail: barbara.fraczek@awf.krakow.pl 
i produktów mlecznych (52,09\%) oraz nieograniczania napojów energetyzujących (59,89\%). Mężczyźni w większym odsetku niż kobiety nie uwzględniali w codziennej diecie: surowych warzyw $(p<0,001)$, pełnoziarnistych produktów zbożowych $(p<0,05)$ i tłuszczów roślinnych $(p<0,01)$. Istotnie częściej także nie ograniczali spożycia: tłuszczów zwierzęcych $(p<0,001)$, słodkich napojów gazowanych $(p<0,001)$, napojów energetyzujących $(p<0,05)$ i produktów fast food $(p<0,001)$. Kobiety mniej regularnie spożywały posiłki $(p<0,01)$, rzadziej spożywały ryby $(p<0,01)$ i częściej nieodpowiednio się nawadniały $(p<0,05)$. Zawodnicy trenujący dyscypliny indywidualne w porównaniu $\mathrm{z}$ trenującymi gry zespołowe rzadziej stosowali odpowiednie napoje nawadniające $(p<0,001)$, a częściej uwzględniali owoce w codziennej diecie $(p<0,05)$. Zawodnicy klasy mistrzowskiej w mniejszym odsetku niż zawodnicy z niższą klasą sportową spożywali posiłki nieregularnie $(p<0,01)$, nie ograniczali tłuszczów zwierzęcych $(p<0,05)$ i nieodpowiednio nawadniali się $(p<0,05)$.

Wnioski: Skala nieprawidłowych wyborów żywieniowych sportowców wykazywała zróżnicowanie w zależności od płci, poziomu sportowego oraz rodzaju uprawianej dyscypliny sportu, przy czym wadliwe zachowania żywieniowe częściej prezentowali mężczyźni niż kobiety oraz zawodnicy o niższym poziomie sportowym (klasy nie-mistrzowskiej). Charakter uprawianej dyscypliny był czynnikiem mniej różnicującym wybory żywieniowe sportowców.

Słowa kluczowe: sportowcy, zachowania żywieniowe, uwarunkowania sposobu żywienia, płeć, poziom sportowy, charakter dyscypliny sportu

\section{INTRODUCTION}

Maintaining health potential and optimizing the effects of sports training is favoured by the implementation of a diverse and balanced diet with high nutritional density, covering the increased demand for energy, selected nutrients and liquids [39, 42]. An illustration of current recommendations for athletes is the model of the Swiss pyramid, which at the base comprises unsweetened beverages, while at the top, we may find sweets, salty snacks and sweetened beverages. Intermediate levels of the pyramid, in turn, include: vegetables and fruits, wholegrain, legume, protein products as well as fats and nuts, recommended for consumption in varying amounts, and at specific frequency [5].

The cited nutritional model emphasizes the special importance of water and other unsweetened beverages for the effective regulation of water and electrolyte balance, as well as vegetables and fruits (products with low and medium glycaemic index, rich in dietary fibre, potassium, magnesium, group B vitamins and antioxidants) for restoring antioxidant status and acid-base balance of the body under physical stress [5, 19, 23, 32, 39, 42, 49]. Incorrect nutritional choices and an unbalanced diet reduce exercise capacity, both indirectly (through negative impact on health and body composition) and directly (via improper nutritional preparation for exercise, improper hydration and weaker post-workout regeneration), and in combination with high intensity training, accelerate the development overtraining syndrome [19, 30, 39, 42].

Assuming that nutritional behaviours (conditioning health, and also, athletes' exercise capacity) are determined by a wide spectrum of environmental and individual factors [4], research has been undertaken regarding selected determinants of nutritional choices among Polish athletes. Previous studies on the determinants of nutritional behaviour of Polish athletes training selected disciplines concerned, among others, the predictive role of psychological factors as well as gender, age and sports level. In these studies, a tendency was shown to make more rational dietary choices among people with a high level of personal resources (self-efficacy, optimism and life satisfaction) $[16,18]$ and women and athletes with a higher sports level [13, $15,17,18]$ At the same time, however, these and other works on determinants of nutrition among competitive athletes, generally focusing on the scale of rational nutritional behaviours, pointed to the legitimacy of further research to verify and clarify relationships between variables and to look for other factors related to the quality of nutritional behaviours. The diet of athletes should be optimized and adapted to individual needs, adequate to gender and type of discipline [34, 40].

Therefore, the conducted study falls under the area of research on factors determining the nutritional behaviour of a representative group of Polish competitive athletes. The aim of the presented research was to assess the scale of incorrect dietary choices among Polish athletes depending on gender, sports level and type of discipline, in relation to the qualitative recommendations of the Swiss sports nutrition pyramid.

\section{MATERIALS AND METHODS}

The research was conducted among Polish athletes competitively training various Olympic sport disciplines, associated in 92 sports clubs from 11 voivodeships. The study included 610 subjects aged 18 to 30 (average age: $22.05 \pm 3.08)$, including 391 men $(64.10 \%)$ and 219 women $(35.90 \%)$. Considering the group as a whole, the most popular were athletes training handball (15.08\%), football (14.43\%), volleyball (13.77\%), track-and-field (11.97\%), swimming (7.87\%), slalom kayaking $(6.89 \%)$, cross-country skiing $(5.08 \%)$, hockey $(4.75 \%)$ and basketball $(4.59 \%)$. The largest percentage of women trained volleyball $(20.09 \%)$, handball $(17.39 \%)$, trackand-field (15.53\%), swimming (9.59\%), basketball and cross-country skiing (5.94\%). The largest percentage of men trained football $(21.74 \%)$, handball $(13.81 \%)$, volleyball (10.23\%), track-and-field (9.97\%), slalom 
kayaking (8.44\%), swimming (6.91\%), hockey (6.14\%), ski jumping (5.12\%), cross-country skiing $(4.60 \%)$ and basketball (3.58\%). Other disciplines were represented less frequently. Individual disciplines were practiced by 289 people $(47.38 \%$ of the sample, including 115 women), and team disciplines by 321 individuals (52.62\% of the sample, including 104 women). Athletes represented a high but varied sports level, from master class to sports class II. The highest, championship, sports class was represented by 282 people, and the I and II sports classes, by a total of 328 subjects.

An original questionnaire was used to assess eating behaviours, which includes 20 diagnostic statements referring to the qualitative assumptions of the Swiss nutrition pyramid for athletes. The claims concerned the frequency and regularity of eating meals, consuming recommended food products (vegetables and fruits, wholegrain cereal products, dairy products, fish and other protein and vegetable oil products), limiting foods not recommended in rational nutrition (confectionery and fast food products, sweetened carbonated beverages and energy drinks), and observing the rules of proper hydration among athletes. With regard to subsequent claims, two categories of choice were adopted: yes and no. The applied questionnaire was subjected to a validation procedure among a group of 43 people from the study population, conducting a retest after 6 weeks. The questionnaire on nutritional behaviour in psychometric assessment, using the $\mathrm{McNemar} \mathrm{Ch}^{2}$ test, obtained high repeatability of results. McNemar $\mathrm{Chi}^{2}$ test values did not show statistically significant differences between test and retest results for any of the statements $(p>0.05)$. Statistical analysis of the results was carried out using Statistica 10 $\mathrm{Pl}$. The distribution of eating behaviours depending on sex, nature of the discipline (team vs. individual) and sports level (master class vs. other) were compared using the $C h i^{2}$ test. A test probability of level of $p<0.05$ was considered statistically significant.

\section{RESULTS}

Regarding the qualitative assumptions of rational nutrition, the whole examined group of athletes, showed incorrect behaviour in the highest percentage regarding: insufficient frequency of vegetable fat $(61.78 \%)$, fruit (and/or fruit juice) (59.89\%), wholegrain cereal $(59.90 \%)$ and vegetable $(53.62 \%)$ as well as dairy product $(52.09 \%)$ consumption. In addition, a high percentage of the athletes did not limit the consumption of energy drinks $(59.89 \%)$ or sweetened carbonated beverages $(45.11 \%)$. About half of the total group consumed meals irregularly $(48.46 \%)$, did not limit the consumption of animal fats $(48.46 \%)$, while fish were eaten less than once a week $(40.36 \%)$. About $1 / 3$ of the group did not hydrate properly during exercise $(39.93 \%)$ and did not prefer water for hydration $(30.67 \%)$. Other improper consumption (less than 3 meals a day, not avoiding fast food and salty or sweet snacks, as well as the implementation of a varied diet) was less common (Table 1).

Table 1. Distribution of irrational nutrition behaviours among Polish athletes according to gender (\%)

\begin{tabular}{|c|c|c|c|c|}
\hline Incorrect nutritional behaviours & Total & Females & Males & $p$ \\
\hline 1. Less than three meals a day & 13.59 & 16.34 & 12.00 & 0.172 \\
\hline 2. Irregular meals & 48.46 & 55.45 & 44.41 & 0.009 \\
\hline 3. Breaks between meals $<3$ or $>5$ hours & 52.18 & 50.25 & 53.30 & 0.426 \\
\hline 4. No fruit (and/or $200 \mathrm{ml}$ of fruit juice) in everyday diet & 59.89 & 63.37 & 57.88 & 0.824 \\
\hline 5. Vegetables less frequently than twice a day & 53.62 & 48.51 & 56.57 & 0.082 \\
\hline 6. Raw vegetables less frequently than once a day & 48.37 & 37.62 & 54.57 & $<0.001$ \\
\hline 7. No cereal products in every meal & 20.00 & 22.86 & 18.24 & 0.620 \\
\hline 8. Wholegrain products less frequently than twice a day & 59.90 & 51.24 & 63.61 & 0.023 \\
\hline 9. Dairy products less frequently than twice a day & 52.09 & 49.50 & 53.58 & 0.252 \\
\hline 10. Protein products (eggs, meat) more frequently than 3 times (or less than twice) a week & 13.43 & 10.40 & 15.19 & 0.134 \\
\hline 11. Fish less frequently than once a week & 40.36 & 48.51 & 35.63 & 0.005 \\
\hline 12. Not limiting consumption of animal fats & 48.46 & 36.82 & 55.14 & $<0.001$ \\
\hline 13. Vegetable fats less frequently than every other day & 61.78 & 56.93 & 64.57 & 0.008 \\
\hline 14. Improper hydration during exercise (much less or much more than 1 litre/h) & 39.93 & 46.27 & 36.29 & 0.038 \\
\hline 15. Not preferring water for body hydration & 30.67 & 30.35 & 30.86 & 0.708 \\
\hline 16.Not avoiding consumption of sweetened carbonated beverages & 45.11 & 35.15 & 50.86 & $<0.001$ \\
\hline 17. Not avoiding consumption of energy drinks & 59.89 & 53.96 & 63.32 & 0.049 \\
\hline 18. Not avoiding consumption of fast food products & 23.77 & 13.67 & 29.80 & $<0.001$ \\
\hline 19. Not limiting consumption of sweet and salty snacks & 25.00 & 21.29 & 27.14 & 0.118 \\
\hline 20. Monotonous, unvaried diet & 27.77 & 28.35 & 26.86 & 0.643 \\
\hline Total index (averaged percentage) & 40.13 & 38.84 & 42.49 & 0.380 \\
\hline
\end{tabular}

$p$ - statistical significance of differences in the $C h i^{2}$ test 
In the statistical analysis, it was shown that men, in a significantly higher percentage than women, did not include the following in their daily diet: raw vegetables $(p<0.001)$, wholegrain cereal products $(p<0.05)$ or vegetable fats $(p<0.01)$. Furthermore, they did not limit the consumption of the following to a greater extent: animal fats $(p<0.001)$, sweetened carbonated beverages $(p<0.001)$, energy drinks $(p<0.05)$ and fast food products $(p<0.001)$. Women, however, ate less regularly $(p<0.01)$, rarely consuming fish $(p<0.01)$, and were more likely to inadequately hydrate the body during exercise $(p<0.05)$ (Table 1$)$.

The assessment of nutritional behaviours depending on the nature of the performed discipline showed that athletes training individual disciplines compared to those training team games significantly less frequently consumed appropriate beverages for hydration $(p<0.001)$, but included fruit in their daily diet more often $(p<0.05)$ (Table 2).

Analysis of nutritional behaviours depending on the sports level showed that the championship class athletes, in a significantly smaller percentage, consumed meals irregularly $(p<0.01)$, did not limit animal fats $(p<0.05)$ and inadequately hydrated the body $(p<0.05)$ compared to competitors of lower (I and II) sports classes (Table 2).

Table 2. Distribution of irrational nutrition behaviours among Polish athletes according to nature of discipline and sports level (\%)

\begin{tabular}{|c|c|c|c|c|c|c|}
\hline \multirow[b]{2}{*}{ Incorrect nutritional behaviours $\mathrm{w}$} & \multicolumn{3}{|c|}{ Type of discipline } & \multicolumn{3}{|c|}{ Sports class } \\
\hline & Individual & Team & $p$ & Championship & $\begin{array}{l}\text { Other } \\
\text { (I\&II) }\end{array}$ & $p$ \\
\hline 1. Less than three meals a day & 11.81 & 15.30 & 0.250 & 13.75 & 13.46 & 0.998 \\
\hline 2. Irregular meals & 47.23 & 49.64 & 0.970 & 40.83 & 54.34 & 0.004 \\
\hline 3. Breaks between meals $<3$ or $>5$ hours & 55.11 & 53.21 & 0.748 & 42.08 & 60.00 & $<0.001$ \\
\hline 4. No fruit (and/or $200 \mathrm{ml}$ of fruit juice) in everyday diet & 55.93 & 63.70 & 0.043 & 58.75 & 60.77 & 0.973 \\
\hline 5. Vegetables less frequently than twice a day & 52.03 & 55.16 & 0.223 & 50.42 & 56.09 & 0.302 \\
\hline 6. Raw vegetables less frequently than once a day & 49.08 & 47.69 & 0.686 & 45.83 & 50.32 & 0.558 \\
\hline 7. No cereal products in every meal & 17.22 & 23.39 & 0.246 & 16.10 & 22.93 & 0.161 \\
\hline 8. Wholegrain products less frequently than twice a day & 55.93 & 62.14 & 0.237 & 55.42 & 61.94 & 0.154 \\
\hline 9. Dairy products less frequently than twice a day & 49.82 & 54.29 & 0.275 & 53.33 & 51.13 & 0.564 \\
\hline $\begin{array}{l}\text { 10. Protein products (eggs, meat) more frequently } \\
\text { than } 3 \text { times (or less than twice) a week }\end{array}$ & 14.81 & 12.1 & 0.3556 & 11.25 & 15.11 & 0.167 \\
\hline 11. Fish less frequently than once a week & 66.67 & 40.71 & 0.949 & 35.15 & 44.37 & 0.053 \\
\hline 12. Not limiting consumption of animal fats & 47.97 & 48.93 & 0.751 & 42.08 & 53.38 & 0.016 \\
\hline 13. Vegetable fats less frequently than every other day & 60.15 & 63.35 & 0.607 & 63.75 & 60.26 & 0.457 \\
\hline $\begin{array}{l}\text { 14. Improper hydration during exercise (much less or } \\
\text { much more than } 1 \text { litre/h) }\end{array}$ & 41.33 & 38.57 & 0.536 & 35.00 & 43.73 & 0.043 \\
\hline 15. Not preferring water for body hydration & 38.15 & 23.49 & $<0.001$ & 30.13 & 31.09 & 0.818 \\
\hline $\begin{array}{l}\text { 16. Not avoiding consumption of sweetened } \\
\text { carbonated beverages }\end{array}$ & 43.17 & 46.98 & 0.330 & 43.75 & 46.15 & 0.502 \\
\hline 17. Not avoiding consumption of energy drinks & 60.37 & 59.43 & 0.938 & 64.44 & 56.41 & 0.077 \\
\hline 18. Not avoiding consumption of fast food products & 21.85 & 25.62 & 0.329 & 21.76 & 25.32 & 0.310 \\
\hline $\begin{array}{l}\text { 19. Not limiting consumption of sweet and salty } \\
\text { snacks }\end{array}$ & 28.04 & 22.06 & 0.100 & 22.92 & 26.60 & 0.352 \\
\hline 20. Monotonous, unvaried diet & 26.57 & 28.93 & 0.405 & 25.52 & 29.49 & 0.424 \\
\hline Total index (averaged percentage) & 42.16 & 41.73 & 0.906 & 38.61 & 43.14 & 0.264 \\
\hline
\end{tabular}




\section{DISCUSSION}

In the presented research, the prevalence of qualitative nutritional mistakes has been shown, therefore, the limited scale of implementation of the qualitative recommendations of the Swiss nutrition pyramid for athletes and the differentiation of some (including incorrect) nutritional behaviours depending on gender, the nature of the discipline and sports level of athletes.

Nutritional mistakes of the examined athletes particularly concerned: insufficient frequency of consuming fruits and vegetables, wholegrain cereal products, dairy products as well as vegetable fats and fish. In addition, the high prevalence of consuming meals irregularly and non-limiting the intake of energy drinks as well as sweetened carbonated beverages and animal fats has been indicated as high. To a lesser extent, athletes demonstrated improper behaviours regarding fluid replenishment strategies. The indicated nutritional mistakes are important for the practice of sports nutrition, because it is reasonably postulated that people representing high physical activity plan their diet and compose meals with the utmost care and nutritional awareness [34].

In sports nutrition, it is recommended to implement dietary strategies to increase, among others, antioxidant potential of the diet [38, 49]. A diet rich in fresh fruit and vegetables, wholegrains, legumes, and sprouts as well as seeds is an effective and safe way to meet the antioxidant needs of physically active people [14]. It has been confirmed that satisfying the increased nutritional needs, also in the field of antioxidants, accelerates muscle regeneration processes and glycogen resynthesis, counteracting fatigue and increasing immunity, while improving the efficiency of preparation for subsequent training and competitions [23, 31].

Mistakes and qualitative nutritional errors found in the examined group of athletes, generally corresponded to the trends described in other studies conducted at both Polish and foreign centres, among competitive athletes of various disciplines. In these studies, the inadequate consumption of some groups of foods with high nutritional density was confirmed, including vegetables and fruits, wholegrains, dairy products and fish, considering Polish athletes participating in team [13] and individual disciplines [18], as well as Spanish [44], Iranian [27] and Portuguese athletes [34], as well as English and Australian footballers [26, 35], Irish and British rugby players [1, 45], Lithuanian athletes of endurance disciplines [3], women training mediumand long-distance running [22] and rally drivers [2].

The low frequency of fruit and vegetable consumption, widespread among athletes, can potentially promote the unbalanced supply of some antioxidant vitamins, which has been confirmed, among others, endurance athletes [36, 41, 43, 46] and athletes participating in the 2010 Games of the Commonwealth of Nations in Dehli [6]. This is unfavourable due to the oxidative stress generated under conditions of physical exercise [49], which justifies implementing dietary strategies that increase the antioxidant potential of the diet (the so-called antioxidative food ration) [49]. The low level of consumption of low-milled cereal products, as well as vegetables and fruits, also promotes deficiencies in $B$ vitamins and magnesium, affecting the reduction of exercise capacity, also described among athletes [10]. It also increases the risk of fibre deficiency in food rations, which has been confirmed among physically active people $[2,50]$. The low consumption of dairy products creates a risk of calcium deficiency, as demonstrated among athletes of various disciplines $[6,11,29,33,50]$. At the same time, it increases the risk of developing osteoporosis, which is an element of the so-called triad of sportswomen. The proper supply of calcium among athletes is particularly important because of its participation in regulating neuromuscular excitability and the acid-base balance of the body [48]. Low consumption of fermented dairy products reduces the consumption of probiotics that affect the maintenance of a diverse and rich intestinal microflora with numerous health-promoting properties $[7,9]$. Low consumption of sea fish may reduce the supply of omega 3 PUFAs with lipid-lowering properties, optimizing blood lipid profile [21]. The small scale of limiting animal fat described in the authors' research corresponds to studies confirming the frequent oversupply of fats, especially saturated fatty acids, e.g. in the diet of Spanish footballers [20], Lithuanian endurance athletes [3] and AZS volleyballers in Białystok [50].

The discussed studies also indicate the diversity of some food choices depending on gender, with an indication of less rational selections among men than women, particularly associated with less frequent consumption of recommended products, including: raw vegetables, wholegrain cereal products and vegetable fats, and higher consumption of non-recommended products, including those high in saturated fatty acids (animal fats), simple sugars (sweetened carbonated beverages, energy drinks) and trans isomers (fast food). However, different trends have been described in the area of other behaviours (irregular meal consumption, insufficient consumption of fish and inadequate hydration during exercise), more often concerning women. Also, in other studies, a variation in eating behaviours has been shown according to gender, including the greater incidence of fruit and vegetable consumption among women [12]. Trends for more 
rational women's food choices than men have also been described among high-class Portuguese athletes during the preparatory and starting periods [34]. Also, in other Polish studies among athletes training individual disciplines and team sports, tendencies towards more rational dietary behaviours of women than men have been shown, which are particularly related to the more frequent consumption of raw vegetables and dairy products with reduced fat content $[13,18]$. The consumption of less recommended products (rich in saturated fatty acids and/or simple sugars) more widespread among the surveyed men corresponded to the tendencies shown among Polish athletes training team games [13], and the youth of Warsaw sports schools [28] as well as American sports students [25]. The less favourable structure of fat intake (animal vs. vegetable) among the surveyed men refers to the results of studies among American students practicing sport, according to which men consumed more saturated fatty acids and cholesterol than women [24].

In the discussed studies, the diversity of some dietary choices has also been shown, depending on the type of discipline and sport level, with an indication of less rational choices among athletes with a lower sports class, particularly associated with greater irregularity of meal consumption, not limiting animal fats and inadequate hydration during exercise compared to athletes representing the championship sports class. The summary of results depending on the type of discipline is less marked (competitors of individual disciplines chose appropriate beverages for hydration to a lesser extent, but consume more fruit than athletes of team disciplines). The differentiation of some dietary choices depending on the level of sport found in this study corresponded to the results of research by other authors'. The works available in the literature relate to the importance of the sports level and variables correlated with it, including age and sports experience $[15,17]$. In the tests conducted for footballers and volleyballers, more rational nutritional behaviours were found among the athletes with higher sports level, including the area of fluid replenishment and fish consumption $[15,17]$.

The trends obtained in the authors' research and the works of other authors confirmed the importance of gender and sports level for the formation of sports nutrition model. These data are also a suggestion for the directions of rationalization of diet depending on the examined individual variables. At the same time, the incomplete implementation of qualitative nutritional recommendations among athletes confirmed the legitimacy of monitoring and targeted rationalization of the diet, taking the quality of nutritional choices into account, including on gender and sports level.
Monitoring nutrition and nutritional status is the basic task of dietitians, implemented in cooperation with the coaching team, playing an important role in motivation and control, aiding the improvement of the nutritional behaviours of athletes [8, 47]. The legitimacy of nutritional education among athletes should be pointed out, which was also claimed by other authors $[37,50]$.

The significance of the work is related to the large size of the group, representing various Olympic sport disciplines, with a high but diverse sports level, from almost the entire country (11 out of 16 voivodeships). Three basic individual characteristics having predictive significance for the quality of food choices were included. Further research could address more psychological and environmental variables as determinants of athletes' nutritional behaviours.

\section{CONCLUSIONS}

1. With reference to the recommendation of the Swiss nutrition pyramid for athletes, numerous mistakes were found in the studied group of Polish high-performance athletes, particularly related to insufficient consumption of vegetables, fruit, lowmilled wholegrain cereal products, dairy products, fish and vegetable fats, and furthermore, without limitation in the consumption of sweet carbonated and energy drinks as well as irregular consumption of meals.

2. The scale of incorrect nutrition choices among athletes showed variation depending on gender, sports level and type of sport practiced, with malnutrition behaviours more often presented by men than women and athletes with a lower sports level (non-master class). The nature of the cultivated discipline was a factor less differentiating the nutritional choices of athletes.

3. The ambiguity of the obtained results suggests the legitimacy of further research into the determinants of nutritional behaviour among high-performance athletes in order to effectively direct dietary counselling.

\section{Conflict of interest}

The authors declare no conflict of interest.

\section{REFERENCES}

1. Alaunyte I., Perry J.L., Aubrey T.: Nutritional knowledge and eating habits of professional rugby league players: does knowledge translate into practice? J Int Soc Sports Nutr 2015; 17(12): 18. doi: 10.1186/ s12970-015-0082-y.

2. Appiah-Dwomoh E.K., Carlsohn A., Mayer F.: Assessment of Dietary Intake of Long-Distance Race Car Drivers-A Pilot Study. Sports (Basel) 2018; 6(4): pii: E118. doi:10.3390/sports6040118. 
3. Baranauskas M., Stukas R., Tubelis L., Žagminas K., Šurkiene G., Švedas E., Giedraitis V.R., Dobrovolskij V., Abaravičius J.A.: Nutritional habits among highperformance endurance athletes. Medicina 2015; 51: 351-362. doi: 10.1016/j.medici.2015.11.004.

4. Birkenhead K.L., Slater G.: A review of factors influencing athletes' food choices. Sports Med 2015; 45(11): 1511-1522. doi: 10.1007/s40279-015-0372-1.

5. Burke L.M.: A food pyramid for Swiss athletes. Int $\mathrm{J}$ Sport Nutr Exerc Metab 2008; 18(4): 430-437.

6. Burkhart S.J., Pelly F.E.: Dietary Intake of Athletes Seeking Nutrition Advice at a Major International Competition. Nutrients 2016; 8(10). pii: E638.

7. Clark A., Mach N.: Exercise-induced stress behavior, gut-microbiota-brain axis and diet: a systematic review for athletes. J Int Soc Sports Nutr 2016; 13: 43.

8. Cockburn E., Fortune A., Briggs M., Rumbold P.: Nutritional Knowledge of UK Coaches. Nutrients 2014; 6(4): 1442-1453. https://doi.org/10.3390/nu6041442.

9. Cronin O., O'Sullivan O., Barton W., Cotter P.D., Molloy M.G., Shanahan F.: Gut microbiota: implications for sports and exercise medicine. Br J Sports Med 2017; 51(9): 700-701. doi: 10.1136/bjsports-2016-097225.

10. Czaja J., Lebiedzińska A., Marszalt M., Szefer $P .:$ Evaluation of magnesium and vitamin B6 supplementation among Polish elite athletes. Rocz Panstw Zakl Hig 2014; 62(4): 413-418.

11. Dobrowolski H., Wtodarek D.: Dietary Intake of Polish Female Soccer Players. Int J Environ Res Public Health 2019; 16(7): 1134. doi: 10.3390/ijerph16071134.

12. Emanuel A.S., McCully S.N., Gallagher K.M., Updegraff J.A.: Theory of Planned Behavior explains gender difference in fruit and vegetable consumption. Appetite 2012; 59(3): 693-697. doi: 10.1016/j.appet.2012.08.007.

13. Fraczek B., Brzozowska E., Morawska M.: Ocena zachowań żywieniowych zawodników trenujących gry zespołowe $\mathrm{w}$ świetle rekomendacji piramidy żywieniowej dla sportowców [Assessment of nutritional habits in athletes practicing team sports in view of the Swiss food pyramid recommendations]. Probl Hig Epidemiol 2013; 94(2): 280-285 (in Polish).

14. Fraczek B., Morawska M., Gacek M., Pogoń K.: Antioxidant activity as well vitamin $\mathrm{C}$ and polyphenol content in the diet for athletes. Italian J Food Sci 2019; 31(4): 617-630. doi. http://dx.doi.org/10.14674/IJFS1510.

15. Gacek M.: Zwyczaje żywieniowe grupy osób wyczynowo uprawiających siatkówkę [Eating habits of a group of professional volleyball players]. Rocz Panstw Zakl Hig 2011; 62(1): 77-82. (in Polish)

16. Gacek M.: Association between self-efficacy and dietary behaviors of American football players in the Polish clubs in the light of dietary recommendations for athletes. Rocz Panstw Zakl Hig 2015; 66(4): 361-366.

17. Gacek M.: Analiza wybranych zachowań żywieniowych grupy piłkarzy nożnych juniorów i seniorów w świetle jakościowych zaleceń dla sportowców [Analysis of Junior and Senior Soccer Players' Eating Habits in Light of Qualitative Recommendations for Sports People]. Probl Hig Epidemiol 2018; 99(3): 289-293 (in Polish).
18. Gacek M.: Selected personal conditions determining the frequency of consuming groups of products among athletes professionally training individual sport disciplines. Hum Mov 2019; 20(3): 56-65. doi: https:// doi.org/10.5114/hm.2019.83997.

19. Galiuto L., Fedele E., Vitale E., Lucini D., Vasilescu M., Ionescu A.M.: Healthy Athlete's Nutrition. Med Sportiva. J Rom Sports Med Soc 2018; 14(1): 29672985.

20. García-Rovés P.M., García-Zapico P., Patterson A.M., Iglesias Gutiérrez E.: Nutrient intake and food habits of soccer players: analyzing the correlates of eating practice. Nutrients 2014; 6(7): 2697-2717. doi: 10.3390/ nu6072697.

21. Gillingham L.G., Harris-Janz S., Jones P.J.: Dietary monounsaturated fatty acids are protective against metabolic syndrome and cardiovascular disease risk factors. Lipids 2011; 46(3): 209-228. doi: 10.1007/ s11745-010-3524-y.

22. Gtabska D., Jusińska M.: Analysis of the choice of food products and the energy value of diets of female middle- and long-distance runners depending on the self-assessment of their nutritional habits. Rocz Panstw Zakl Hig 2018; 69(2): 155-163.

23. Heaton L., Davis J., Rawson E., Nuccio R., Witard O., Stein K., Baar K., Carter J., Baker L.: Selected In-Season Nutritional Strategies to Enhance Recovery for Team Sport Athletes: A Practical Overview. Sports Med 2017; 47: 2201-2218. doi: 10.1007/s40279-017-0759-2.

24. Hinton P.S., Sanford T.C., Davidson M.M., Yakushko O.F., BeckN.C.: Nutrient intakes and dietary behaviors of male and female collegiate athletes. Int J Sport Nutr Exerc Metab 2004; 14(4): 389-405.

25. Hull M.V., Jagim A.R., Oliver J.M., Greenwood M. Busteed D.R., Jones M.T.: Gender differences and access to a sports dietitian influence dietary habits of collegiate athletes. J Int Soc Sports Nutr 2016; 13: 38.

26. Jenner S.L., Trakman G., Coutts A., Kempton T., Ryan S., Forsyth A., Belski R.: Dietary intake of professional Australian football athletes surrounding body composition assessment. J Int Soc Sports Nutr 2018; 15(1): 43. doi: 10.1186/s12970-018-0248-5.

27. Jessri M., Jessri M., Rashid Khani B., Zinn C.: Evaluation of Iranian college athletes' sport nutrition knowledge. Int J Sport Nutr Exerc Metab 2010; 20(3): 257-263.

28. Łagowska K., Woźniewicz M., Jeszka J.: Porównanie nawyków żywieniowych młodzieży z uwzględnieniem płci oraz poziomu aktywności fizycznej [Comparison of eating habits among students with admitted sex and level of physical activity]. Rocz Panstw Zakl Hig 2011; 62(3): 335-342 (in Polish).

29. Maughan R.J., Shirreffs S.M.: Nutrition and hydration concerns of the female football player. Br J Sports Med 2007; 41(suppl. 1): 60 -63.

30. Maffetone P.B., Laursen P.B.: Athletes: Fit but Unhealthy? Sports Medicine Open 2016; 2: 24. doi: 10.1186/s40798-016-0048-x.

31. Myburgh K.: Polyphenol Supplementation: Benefits for Exercise Performance or Oxidative Stress? Sports Med 2014; 44: 57-70. 
32. Naderi A., Adel M., Conrad P.E., Kyle L., Sajjad R.: Fruit for sport. Trends Food Sci Technol 2018; 74: 85-98.

33. Noda Y., Iide K., Masuda R., Kishida R., Nagata A., Hirakawa F., Yoshimura Y., Imamura H.: Nutrient intake and blood iron status of male collegiate soccer players. Asia Pac J Clin Nutr 2009; 18(3): 344-350.

34. Nunes C.L., Matias C.N., Santos D.A., Morgado J.P., Monteiro C.P., Sousa M., Minderico C.S., Rocha P.M., St-Onge M.P., Sardinha L.B., Silva A.M.: Characterization and Comparison of Nutritional Intake between Preparatory and Competitive Phase of Highly Trained Athletes. Medicina (Kaunas) 2018; 54(3). pii: E41. doi: 10.3390/medicina54030041.

35. Ono M., Kennedy E., Reeves S., Cronin L.: Nutrition and culture in professional football. A mixed method approach. Appetite 2012; 58(1): 98-104. doi: 10.1016/j. appet.2011.10.007.

36. Pilis K., Michalski C., Zych M., Pilis A., Jelonek J., Kaczmarzyk A., Pilis W.: A nutritional evaluation of dietary behaviour in various professional sports. Rocz Panstw Zakl Hig 2014; 65(3): 227-234.

37. Pilis K., Stec K., Pilis A., Mroczek A., Michalski C., Pilis $W$.: Body composition and nutrition of female athletes. Rocz Panstw Zakl Hig 2019; 70(3): 243-251.

38. Pingitore A., Lima G.P., Mastorci F., Quinones A., Iervasi $G$., Vassalle $C$.: Exercise and oxidative stress: potential effects of antioxidant dietary strategies in sports. Nutrition 2015; 31(7-8): 916-922. doi: 10.1016/j. nut.2015.02.005

39. Potgieter S.: Sport nutrition: A review of the latest guidelines for exercise and sport nutrition from the American College of Sport Nutrition, the International Olympic Committee and the International Society for Sports Nutrition. S Afr J Clin Nutr 2013; 26(1): 6-16.

40. Rossi K.A.: Nutritional Aspects of the Female Athlete. Clin Sports Med 2017; 36(4): 627-653. doi: 10.1016/j. csm.2017.05.007.

41. Stellingwerff T.: Competition nutrition practices of elite ultramarathon runners. Int J Sport Nutr Exerc Metab 2016; 26(1): 93-99. doi: 10.1123/ijsnem.2015-0030.
42. Thomas D.T., Erdmann K.A., Burke L.M.: Position of the Academy of Nutrition and Dietetics, Dietitians of Canada, and the American College of Sports Medicine: Nutrition and Athletic Performance. J Acad Nutr Diet 2016; 116: 501-528. doi: 10.1016/j.jand.2015.12.006.

43. Tota Ł., Pilch W., Hodur M., Sagalara A.: Assessment of diet of young medium-and long-distance runners. Med Sportiva 2013; 17(1): 18-23.

44. Ubeda N., Palacios Gil-Antuñano N., Montalvo Zenarruzabeitia Z., García Juan B., García A., IglesiasGutiérrez E.: Food habits and body composition of Spanish elite athletes in combat sports. Nutr Hosp 2010; 25(3): 414-421.

45. Walsh M., Cartwright L., Corish C., Sugrue S., WoodMartin R.: The body composition, nutritional knowledge, attitudes, behaviors, and future education needs of senior schoolboy rugby players in Ireland. Int J Sport Nutr Exerc Metab 2011; 21(5): 365-376.

46. Wierniuk A., Włodarek D.: Estimation of energy and nutritional intake of young men practicing aerobic sports. Rocz Panstw Zakl Hig 2013; 64(2): 143-148.

47. Valliant M.W., Emplaincourt H., Wenzel R., Garner B.: Nutrition education by a registered dietitian improves dietary intake and nutrition knowledge of a NCAA female volleyball team. Nutrients 2012; 4: 506-516.

48. Volpe S.L.: Micronutrient requirements for athletes. Clin Sports Med 2007; 26(1): 119-130.

49. Yavari A., Javadi M., Mirmiran P., Bahadoran Z.: Exercise-Induced Oxidative Stress and Dietary Antioxidants. Asian J Sports Med 2015; 6: e24898.

50. Zapolska J., Witczak K., Mańczuk A., Ostrowska L.: Assessment of nutrition, supplementation and body composition parameters on the example of professional volleyball players. Rocz Panstw Zakl Hig 2014; 65(3): 235-242.

Received: 03.02.2020

Accepted: 06.03.2020 